\title{
Serum iron as an indicator of acute inflammation in cattle ${ }^{1}$
}

\author{
Ersoy Baydar ${ }^{2}$ and Murat Dabak \\ Firat University, Veterinary Faculty, Department of Internal Medicine, 23119 Elaziğ, Turkey
}

\begin{abstract}
The aim of this study was to assess the value of serum iron concentration in the diagnosis of acute inflammation in cattle. The diagnostic value of this approach was compared with that of various other hematological tests, including commonly used techniques that measure the levels of various other acute-phase proteins. The study population comprised 10 cows with acute traumatic reticuloperitonitis (RPT group) and 10 cows with acute mastitis (mastitis group) admitted to the Veterinary Teaching Hospital at Firat University (Elaziğ, Turkey). Ten cows from local barns, kept and fed under same conditions as the diseased animals, were used as controls. After the clinical examination, blood samples were collected for biochemical, hematological, and acute-phase protein (haptoglobin, serum amyloid A, $\alpha-1$ acid glycoprotein, and fibrinogen) analyses. The mean levels of serum iron in the RPT, mastitis, and control groups were $6.00,7.82$, and $26.78 \mu \mathrm{mol} / \mathrm{L}$, respectively. Serum iron level was significantly reduced in the RPT and mastitis groups. The results of this study indicate that serum iron analysis, preferably in combination with other markers of inflammation, may be a useful diagnostic tool for acute inflammation in cattle. Because serum iron measurement is individually available and easily applicable, it may be used for clinical cases as well as the determination of herd health.
\end{abstract}

Key words: acute inflammation, acute-phase protein, cattle, iron

\section{INTRODUCTION}

Inflammation is a complex response to cell or tissue injury. This response dilutes, eliminates, or incapacitates agents that are injurious to the organism and then initiates the reconstruction and recovery of damaged cells and tissues (Cheville, 1999; Baron and Lee, 2006). Inflammation is usually classified as acute or chronic (Ward, 2010).

\footnotetext{
Received April 19, 2013.

Accepted October 8, 2013.

${ }^{1}$ This manuscript represents a portion of the $\mathrm{PhD}$ thesis submitted by Ersoy Baydar.

${ }^{2}$ Corresponding author: ebaydar@firat.edu.tr
}

Acute inflammation develops over minutes or hours, depending on the type and severity of the tissue damage and generally lasts hours to days (Kumar and Wakefield, 2010). Acute inflammation involves the leakage of water, salt, and proteins from the vascular compartment; endothelial cell activation; adhesive interactions between leukocytes and the vascular endothelium; leukocyte recruitment; macrophage activation; platelet activation and aggregation; activation of the complement, clotting, and fibrinolytic systems; and the release of proteases and oxidants from phagocytic cells to cope with the injury (Ward, 2010). Clinically, the integration of these phases manifests as redness, heat, swelling, pain, and a loss of function (Baron and Lee, 2006; Ward, 2010).

Chronic inflammation lasts longer than acute inflammation (weeks or months) and often results from the organism's failure to eliminate an acute inflammatory irritant or an autoimmune response to a self-antigen. The persistence of an innately chronic irritant of low intensity can also trigger chronic inflammation. Chronic inflammation is characterized by simultaneous inflammation and repair, including the recruitment and activation of macrophages, lymphocytes, and other cells. These processes are regulated by the coordinated action of cytokines and growth factors (Ward et al., 1996; Baron and Lee, 2006).

Numerous bovine diseases are associated with acute inflammation, but the arsenal of the practicing veterinarian includes only a limited number of laboratory tests for the diagnosis of inflammation. Total and differential white blood cell (WBC) counts and acutephase proteins (APP) analyses are the tools most commonly used for the diagnosis of bovine inflammatory diseases (Hirvonen, 2000; Murata et al., 2004; Petersen et al., 2004; Ceciliani et al., 2012). Studies indicate that serum Fe concentration could also be used as a marker of acute inflammation in humans and certain other animal species (Ward et al., 1996; Sunder-Plamann et al., 1999; Neumann, 2003; Borges et al., 2007). Serum Fe concentration decreases rapidly in response to inflammation. This host defense mechanism aims to withhold the Fe required for bacterial virulence and replication (Borges et al., 2007). Serum Fe concentration has been evaluated as a marker of inflammation in dogs 
(Neumann, 2003), cats (Neumann, 2003), and horses (Jacobsen et al., 2005; Borges et al., 2007), but limited data exist about whether serum Fe concentration can be used to diagnose acute inflammation in cattle.

The present investigation was undertaken to assess the value of serum Fe concentration in the diagnosis of acute inflammation in cattle. The diagnostic value of this approach was compared with that of the hematological tests and APP used currently.

\section{MATERIALS AND METHODS}

The study population comprised 10 cows with acute traumatic reticuloperitonitis (RPT) and 10 cows with acute mastitis admitted to the Veterinary Teaching Hospital at Firat University (Elaziğ, Turkey). Ten cows from local barns, kept and fed under the same conditions as the diseased animals, were included as controls. All the cows underwent a detailed clinical examination (Radostits, 2000). The tentative diagnosis of acute RPT was based on the results of physical, ferroscopic (Hauptner Ferroscope, Art-Nr 39500; H. Hauptner \& Richard Herberholz GmbH \& Co. KG, Solingen, Germany), and ultrasonographic (LOGIQ Book XP Vet; GE Medical Systems Co. Ltd., Wuxi, China) examinations. A rumenotomy was conducted in the hospital to confirm this diagnosis. Acute mastitis was diagnosed clinically based on the results of the clinical examination. Microbiological examinations were performed to confirm a California mastitis test (CMT) diagnosis. The animals that were not treated with any drugs and in which the course of the clinical disease was not longer than $72 \mathrm{~h}$, were included in RPT or mastitis groups. All animals were fed a ration of concentrate diet, straw, and dried alfalfa. Estimated levels of $\mathrm{NE}_{\mathrm{L}}$ and $\mathrm{CP}$ of the diet were $5.9 \mathrm{MJ} / \mathrm{kg}$ of $\mathrm{DM}$ and $146 \mathrm{~g} / \mathrm{kg}$ of DM, respectively.

\section{Blood and Milk Sample Collection}

Blood samples were taken from the jugular vein of each cow into the Vacutainers (Becton Dickinson, Franklin Lakes, NJ) with and without EDTA for hematological and biochemical (including $\mathrm{Fe}$ ) analysis, respectively. The serum was separated by centrifugation at $750 \times g$ for $15 \mathrm{~min}$ at $4^{\circ} \mathrm{C}$ within a period of 2 $\mathrm{h}$ maximum after sampling and stored at $-20^{\circ} \mathrm{C}$ until use. Blood samples were used for hematological and fibrinogen analyses within a period of $2 \mathrm{~h}$ maximum after sampling. Milk samples were stored in plastic CMT wells for the CMT and in sterilized tubes for the microbiologic culture antibiogram.

\section{CMT}

Samples from each of the cows in the mastitis and control groups were submitted to the CMT described by Schalm and Noorlander (1957).

\section{Biochemical Examinations}

Serum alanine aminotransferase, aspartate aminotransferase, alkaline phosphatase, gamma glutamyl transferase, ammonia $\left(\mathrm{NH}_{3}\right)$, total protein $(\mathbf{T P})$, total bilirubin, BUN, creatinine, creatine kinase, glucose (GLU), albumin (ALB), and Fe levels were determined through biochemical analysis by using specific test slides for a dry system autoanalyzer (Vitros DT 60; Johnson \& Johnson Clinical Diagnostics Ltd., Buckinghamshire, UK).

The method for measuring serum $\mathrm{Fe}$ is described briefly below. The Vitros Fe DT slide is a multilayered, analytical element coated on a polyester support. A drop of serum sample is deposited on the slide and is evenly distributed by the spreading layer to the underlying layers. Iron (as ferric ion) is removed from transferrin at acidic $\mathrm{pH}$ and migrates to the reducing layer, where ascorbic acid reduces Fe to the ferrous form. The ferrous ion then is bound to the dye and forms a colored complex. Within-laboratory coefficients of variation for Fe were 3.0 and $2.8 \%$.

\section{Hematologic Examinations}

Red blood cell and white blood cell (WBC) count, hemoglobin $(\mathbf{H b})$ level, packed cell volume, mean corpuscular volume, mean corpuscular $\mathrm{Hb}(\mathbf{M C H})$, and $\mathrm{MCH}$ concentration measurements were obtained by using manual techniques (Morris, 2009). Blood smears were prepared on slides and stained using the MayGrünwald-Giemsa solution in phosphate buffer $(\mathrm{pH}$ 6.8). The blood smears were examined to identify WBC subtypes [neutrophils (band), neutrophils (segmented), lymphocytes, monocytes, eosinophils, and basophils] using a light microscope (Harvey, 2001; Thrall, 2006).

\section{Analysis of APP}

Serum haptoglobin (Hp) was measured using an $\mathrm{Hb}-$ binding biochemical reaction, which can be used on a microtiter (ELISA) plate (Tridelta Development Plc, Greystones, Co. Wicklow, Ireland). Serum amyloid A (SAA; Tridelta Development Plc) was measured using a solid-phase sandwich ELISA (ESR 200 ELISA Plate Reader; Medispec Ltd., Germantown, MD). Serum $\alpha-1$ acid glycoprotein (AGP) levels were measured using 
Table 1. Rectal temperature (RT), respiratory rate (RR), heart rate (HR), ruminal contraction (RC), reporting age, parity, and DIM values (mean \pm SD) for animals in the control, mastitis, and traumatic reticuloperitonitis (RPT) groups

\begin{tabular}{lcccc}
\hline Variable & Control & Mastitis & RPT & $P$-value \\
\hline RT $\left({ }^{\circ} \mathrm{C}\right)$ & $38.49 \pm 0.35^{\mathrm{a}}$ & $39.66 \pm 0.65^{\mathrm{b}}$ & $39.34 \pm 0.50^{\mathrm{b}}$ & $* *$ \\
$\mathrm{RR}$ (breaths/min) & $29.20 \pm 7.55$ & $29.60 \pm 6.85$ & $23.20 \pm 6.19$ & - \\
$\mathrm{HR}$ (beats/min) & $79.60 \pm 7.87$ & $86.40 \pm 15.34$ & $74.80 \pm 9.05$ & - \\
$\mathrm{RC}(/ 5$ min) & $9.60 \pm 1.26^{\mathrm{a}}$ & $6.40 \pm 3.37^{\mathrm{ab}}$ & $4.10 \pm 1.595^{\mathrm{b}}$ & $* *$ \\
Reporting age & $4.70 \pm 1.15$ & $4.80 \pm 1.22$ & $5.10 \pm 1.96$ & - \\
Parity & $2.00 \pm 0.66$ & $2.20 \pm 0.78$ & $2.70 \pm 1.63$ & $*-16^{\mathrm{b}}$ \\
DIM & $141.00 \pm 62.97^{\mathrm{a}}$ & $66.00 \pm 17.76^{\mathrm{a}}$ & $208.00 \pm 45.16^{\mathrm{b}}$ & $* * *$ \\
\hline
\end{tabular}

${ }^{\mathrm{a}, \mathrm{b}}$ Values within a row with different superscript letters are significantly different $(P<0.05)$.

** $P<0.01 ; * * * P<0.001$.

bovine radial immunodiffusion assay kits (Tridelta Development $\mathrm{Plc})$.

Plasma fibrinogen (Fb) levels were measured using the heat-precipitation method; protein levels were measured using a refractometer (Coles, 1986; portable refractometer, model FG302/311; Chincan Scientific Instruments, Beijing, China). Briefly, 2 capillary tubes were filled with blood (EDTA) and spun in a highspeed microhematocrit centrifuge at 12,000 $\times g$ for 5 min at $4^{\circ} \mathrm{C}$ to clear the plasma. The TP concentration in the plasma of one tube was determined using a refractometer. The other tube was immersed in a water bath at $57^{\circ} \mathrm{C}$ for 3 min to precipitate $\mathrm{Fb}$. It was centrifuged again at $12,000 \times g$ for 5 min at $4^{\circ} \mathrm{C}$, and the TP concentration of the remaining plasma was determined. The difference between the 2 measurements was the $\mathrm{Fb}$ concentration.

\section{Statistical Analyses}

Statistical analyses were performed using SPSS software (SPSS version 13.0 for Windows; SPSS Inc., Chicago, IL). Group means were compared using the Kruskal-Wallis test $(P<0.05)$. The Mann-Whitney U test was used with a Bonferroni correction to assess differences among the 3 groups. A $P$-value of $<0.05$ was considered statistically significant.

\section{RESULTS}

The rectal temperature, respiratory rate, heart rate, ruminal contraction, reporting age, parity, and DIM values are presented in Table 1 . The ages of animals in the RPT group ranged from 3 to $9 \mathrm{yr}$. The RPT cows exhibited anorexia, moaning, constipation, weight loss, arched backs, sharp decreases in milk production, a reluctance to rise or move, and anxiety. Lower-joint abduction was also observed, indicating cranial abdominal pain. Other clinical signs included repeated ruminal tympany, dehydration, ruminal stasis and impaction, and abdominal tension. Ferroscopy revealed metallic foreign bodies in the reticular area, and ultrasonographic images showed fibrous changes that appeared as echogenic deposits. Reticular abscesses were also seen as echogenic capsules with a hypoechogenic center. Rumenotomy revealed that metallic foreign bodies had perforated the reticular wall of each animal in the RPT group.

The ages of animals in the mastitis group ranged from 3 to 7 yr. Cows in the mastitis group exhibited reduced appetite, redness, asymmetry, swelling, warmth, and pain in the affected udder lobe. The milk produced by these animals was modest and full of clots. The microbiological examination of milk samples from the mastitis group identified Staphylococcus spp. and Escherichia coli as causative agents.

The ages of the control animals ranged from 3 to 7 yr. The general condition, appetite, rumination, defecation, and mucosae of all animals in the control group were in acceptable conditions. The control animals yielded negative results on the ferroscopic examination and the CMT.

The serum alanine aminotransferase, aspartate aminotransferase, alkaline phosphatase, gamma glutamyl transferase, $\mathrm{NH}_{3}$, TP, total bilirubin, BUN, creatinine, creatine kinase, GLU, and ALB levels of all the study animals are presented in Table 2. The corresponding red blood cell, $\mathrm{Hb}$, packed cell volume, mean corpuscular volume, $\mathrm{MCH}$, and $\mathrm{MCH}$ concentration levels are presented in Table 3. Table 4 presents the $\mathrm{WBC}$ and differential WBC counts as well as the Hp, SAA, AGP, $\mathrm{Fb}$, and Fe levels for all groups.

\section{DISCUSSION}

The ability to identify inflammation in its early stages is crucial for clinical diagnosis, herd health, and animal welfare. The appropriate laboratory tests would facilitate such a diagnosis (Horadagoda et al., 1999; Hirvonen, 2000; Jones and Allison, 2007). At the pres- 
Table 2. Alanine aminotransferase (ALT), aspartate aminotransferase (AST), alkaline phosphatase (ALKP), gamma glutamyl transferase (GGT), ammonia $\left(\mathrm{NH}_{3}\right)$, total protein (TP), total bilirubin (TB), BUN, creatinine (CRSC), creatine kinase (CK), glucose (GLU), and albumin (ALB) levels (mean $\pm \mathrm{SD}$ ) in control, mastitis, and traumatic reticuloperitonitis (RPT) animals

\begin{tabular}{lccrc}
\hline Item & Control & \multicolumn{1}{c}{ Mastitis } & \multicolumn{1}{c}{ RPT } & $P$-value \\
\hline ALT $(\mathrm{U} / \mathrm{L})$ & $49.70 \pm 12.74$ & $55.30 \pm 19.17$ & $52.50 \pm 18.89$ & - \\
AST $(\mathrm{U} / \mathrm{L})$ & $77.10 \pm 24.60$ & $89.00 \pm 30.62$ & $103.60 \pm 41.45$ & - \\
$\mathrm{ALKP}(\mathrm{U} / \mathrm{L})$ & $65.90 \pm 45.42$ & $58.10 \pm 34.84$ & $67.00 \pm 36.12$ & - \\
$\mathrm{GGT}(\mathrm{U} / \mathrm{L})$ & $31.50 \pm 9.26^{\mathrm{a}}$ & $49.40 \pm 13.13^{\mathrm{b}}$ & $46.20 \pm 8.18^{\mathrm{b}}$ & $* *$ \\
$\mathrm{NH}_{3}(\mu \mathrm{mol} / \mathrm{L})$ & $85.40 \pm 61.75$ & $73.72 \pm 32.86$ & $103.78 \pm 47.68$ & - \\
$\mathrm{TP}(\mathrm{g} / \mathrm{L})$ & $69.40 \pm 3.80^{\mathrm{a}}$ & $77.1 \pm 8.90^{\mathrm{ab}}$ & $77.3 \pm 7.50^{\mathrm{b}}$ & $* *$ \\
TB $(\mu \mathrm{mol} / \mathrm{L})$ & $3.08 \pm 2.05$ & $3.59 \pm 2.74$ & $4.10 \pm 4.45$ & - \\
$\mathrm{BUN}(\mathrm{mmol} / \mathrm{L})$ & $3.14 \pm 1.34^{\mathrm{a}}$ & $3.78 \pm 1.41^{\mathrm{ab}}$ & $4.89 \pm 1.06^{\mathrm{b}}$ & $* *$ \\
$\mathrm{CRSC}(\mu \mathrm{mol} / \mathrm{L})$ & $95.47 \pm 30.06$ & $124.64 \pm 78.68$ & $94.59 \pm 15.91$ & - \\
$\mathrm{CK}(\mathrm{U} / \mathrm{L})$ & $159.00 \pm 79.56$ & $106.50 \pm 53.23$ & $278.70 \pm 416.59$ & - \\
GLU $(\mathrm{mmol} / \mathrm{L})$ & $2.24 \pm 1.6$ & $2.52 \pm 1.21$ & $3.39 \pm 1.14$ & - \\
ALB $(\mathrm{g} / \mathrm{L})$ & $26.30 \pm 6.20$ & $28.70 \pm 4.50$ & $31.70 \pm 3.70$ & - \\
\hline
\end{tabular}

$\overline{\mathrm{a}, \mathrm{b}}$ Values within a row with different superscript letters are significantly different $(P<0.05)$.

** $P<0.01$

ent time, acute inflammation is usually identified in cattle based on the WBC count, the differential WBC count, and APP analyses.

In the present study, WBC counts were similar in all of the study groups. The band (immature) neutrophil ratio was significantly increased in the mastitis and RPT groups compared with the controls, indicating a regenerative left shift. In cattle, acute inflammation and infection can induce similar changes in the WBC count. These rapid changes reflect the migration of neutrophils to the site of inflammation, the margination of neutrophils, and a stress-induced reduction in the number of lymphocytes (Thrall, 2006; Jones and Allison, 2007; Morris, 2009). A regenerative left shift represents a strong bone-marrow response to inflammation. Such a response can include increased neutrophil production, which results in increased numbers of segmented neutrophils and bands, with more segmented neutrophils than bands formed (Jones and Allison, 2007; Morris, 2009). Despite their value in the treatment of humans and several other animal species, altered neutrophil ratios are usually considered as unreliable in the diagnosis of acute inflammation in cattle (Ward et al., 1996;
Sunder-Plasmann et al., 1999; Neumann, 2003; Borges et al., 2007). This skepticism stems from the fact that adult cattle do not have sufficient segmented and band neutrophil bone-marrow storage pools to allow for release into the circulation (Jones and Allison, 2007; Morris, 2009). Therefore, severe inflammation can persist in cattle despite initial neutropenia over the first 24 to $48 \mathrm{~h}$ of an infection (Jones and Allison, 2007).

Acute inflammation causes a nonspecific systemic reaction denoted as the acute-phase response (APR). During the APR, proteins called APP are released into the circulation (Petersen et al., 2004; Gruys et al., 2005). Acute-phase proteins are synthesized in the liver. Plasma concentrations of some of these proteins increase several hundred fold in response to inflammatory cytokines, such as IL-6, IL-1, and TNF- $\alpha$ (Petersen et al., 2004). The function of APP is to promote immunoglobulin production and tissue repair, which prevents further injury and recycles cellular debris (Thomas, 2000; Gruys et al., 2005). Haptoglobin, SAA, AGP, and $\mathrm{Fb}$ are well-known bovine APP that are often used as markers of acute inflammation in cattle (Horadagoda et al., 1999; Gånheim et al., 2007; Jones and Allison,

Table 3. Red blood cell (RBC), hemoglobin (Hb), packed cell volume (PCV), mean corpuscular volume (MCV), mean corpuscular hemoglobin (MCH), and mean corpuscular hemoglobin concentration (MCHC) values (mean $\pm \mathrm{SD}$ ) for control, mastitis, and traumatic reticuloperitonitis (RPT) animals

\begin{tabular}{lcccc}
\hline Item & Control & Mastitis & RPT & $P$-value \\
\hline $\mathrm{RBC}\left(\times 10^{12} / \mathrm{L}\right)$ & $5.65 \pm 0.59$ & $5.81 \pm 1.27$ & $5.17 \pm 0.92$ & - \\
$\mathrm{Hb}(\mathrm{g} / \mathrm{L})$ & $107.8 \pm 11.3$ & $101.5 \pm 17.4$ & $94.5 \pm 12.5$ & - \\
$\mathrm{PCV}\left(\times 10^{-2} \mathrm{~L} / \mathrm{L}\right)$ & $0.33 \pm 0.03^{\mathrm{a}}$ & $0.31 \pm 0.03^{\mathrm{ab}}$ & $0.29 \pm 0.02^{\mathrm{b}}$ & $* *$ \\
$\mathrm{MCV}(\mathrm{fL})$ & $59.58 \pm 4.80$ & $55.06 \pm 9.70$ & $57.18 \pm 8.51$ & - \\
$\mathrm{MCH}(\mathrm{gg})$ & $19.14 \pm 1.37$ & $18.17 \pm 4.07$ & $18.80 \pm 4.14$ & - \\
$\mathrm{MCHC}(\mathrm{g} / \mathrm{L})$ & $318.3 \pm 24.5$ & $328.2 \pm 38.2$ & $326.6 \pm 38.0$ & - \\
\hline
\end{tabular}

${ }^{\mathrm{a}, \mathrm{b}}$ Values within a row with different superscript letters are significantly different $(P<0.05)$.

$* * P<0.01$. 
Table 4. White blood cells (WBC), differentiated WBC counts, haptoglobin (Hp), serum amyloid A (SAA), $\alpha$-1-acid glycoprotein (AGP), fibrinogen $(\mathrm{Fb})$, and Fe levels (mean $\pm \mathrm{SD}$ ) for animals in the control, mastitis, and traumatic reticuloperitonitis (RPT) groups

\begin{tabular}{lcccc}
\hline Item & Control & Mastitis & RPT & $P$-value \\
\hline WBC $\left(\times 10^{9} / \mathrm{L}\right)$ & $6.51 \pm 2.00$ & $4.88 \pm 3.03$ & $6.73 \pm 2.80$ & - \\
Neutrophils, band (\%) & $1.0 \pm 0.94^{\mathrm{a}}$ & $22.6 \pm 20.3^{\mathrm{b}}$ & $10.6 \pm 8.1^{\mathrm{b}}$ & $* *$ \\
Neutrophils, segmented $(\%)$ & $30.4 \pm 15.6^{\mathrm{a}}$ & $27.2 \pm 11.6^{\mathrm{ab}}$ & $42.9 \pm 13.2^{\mathrm{ac}}$ & $* *$ \\
Lymphocytes (\%) & $63.10 \pm 17.67^{\mathrm{a}}$ & $37.00 \pm 11.61^{\mathrm{b}}$ & $38.70 \pm 12.48^{\mathrm{b}}$ & $* *$ \\
Monocytes (\%) & $3.00 \pm 2.53$ & $3.20 \pm 2.82$ & $3.90 \pm 2.68$ & - \\
Eosinophils (\%) & $2.10 \pm 2.18$ & $7.50 \pm 8.69$ & $3.80 \pm 3.11$ & - \\
Basophils (\%) & $0.40 \pm 0.51$ & $0.30 \pm 0.67$ & $0.20 \pm 0.42$ & - \\
Hp $(\mathrm{mg} / \mathrm{L})$ & $60.0 \pm 20.0^{\mathrm{a}}$ & $440.0 \pm 500.0^{\mathrm{ab}}$ & $730.0 \pm 250.0^{\mathrm{b}}$ & $* *$ \\
SAA $(\mu \mathrm{g} / \mathrm{mL})$ & $18.50 \pm 14.18^{\mathrm{a}}$ & $89.95 \pm 28.70^{\mathrm{b}}$ & $110.80 \pm 10.58^{\mathrm{b}}$ & $* *$ \\
AGP $(\mu \mathrm{g} / \mathrm{mL})$ & $285.50 \pm 254.30^{\mathrm{a}}$ & $998.50 \pm 762.77^{\mathrm{ab}}$ & $1,251.00 \pm 908.79^{\mathrm{b}}$ & $* *$ \\
Fb $(\mu \mathrm{mol} / \mathrm{L})$ & $9.41 \pm 3.04^{\mathrm{a}}$ & $17.05 \pm 9.78^{\mathrm{ab}}$ & $27.64 \pm 9.62^{\mathrm{b}}$ & $* *$ \\
Fe $(\mu \mathrm{mol} / \mathrm{L})$ & $26.78 \pm 4.59^{\mathrm{a}}$ & $7.82 \pm 4.48^{\mathrm{b}}$ & $6.00 \pm 3.16^{\mathrm{b}}$ & $* *$ \\
\hline
\end{tabular}

${ }^{a-c}$ Values within a row with different superscript letters are significantly different $(P<0.05)$.

$* * P<0.01$.

2007). In the present study, Hp, SAA, AGP, and $\mathrm{Fb}$ levels were increased in both the mastitis and RPT groups compared with the controls, as reported previously. This increase was statistically important for all APP in the RPT group, but only for SAA in the mastitis group. The discrepancy between the mastitis and RPT groups is likely due to differences in the beginning of the inflammation or in the levels of cytokines, which are responsible for the production and secretion of APP (Horadagoda et al., 1999). Although APP levels roughly reflect the intensity of inflammation, measurements of some APP are expensive and are not commonly available in veterinary diagnostic laboratories yet (Samols et al., 2002; Petersen et al., 2004; Gruys et al., 2005; Gånheim et al., 2007).

It has been reported that the decrease in serum Fe levels observed during the APR might represent a useful tool for the diagnosis and prognosis of acute inflammatory diseases in humans and certain animal species (Ward et al., 1996; Sunder-Plasmann et al., 1999; Neumann, 2003; Borges et al., 2007). Plasma Fe levels decrease rapidly within $24 \mathrm{~h}$ after the initiation of inflammation (Forsberg and Bullen, 1972; Hayes, 1994; Kluger and Rothenburg, 1979; Lohuis et al., 1988a,b; Ratledge and Dover, 2000). This reduction in plasma Fe levels stems from decreased intestinal absorption and less Fe release by reticuloendothelial cells (Hershko et al., 1974; Nemeth et al., 2004; De Domenico et al., 2007; Andriopoulos et al., 2009; Cherayil, 2011). This decrease in plasma Fe levels enhances the organism's nonspecific resistance to bacterial infection (Kluger and Rothenburg, 1979; Ward et al., 1996; Sunder-Plasmann et al., 1999). A low-Fe environment, which is a consequence of Fe sequestration in the body for control of bacterial proliferation, is essential for bacteriostatic systems in the body (Ward et al., 1996; Sunder-Plasmann et al., 1999). It has been reported that serum Fe levels decreased in $90 \%$ of cats and $60 \%$ of dogs with inflammatory disease (Neumann, 2003). Borges et al. (2007) investigated the diagnostic value of plasma Fe levels in horses with systemic inflammation and reported that plasma Fe level is a sensitive marker that is superior to plasma $\mathrm{Fb}$ concentration in the detection of systemic inflammation in horses. In horses with experimentally induced inflammation, serum Fe decreased within the first $24 \mathrm{~h}$ and returned to normal levels within $6 \mathrm{~d}$ (Smith and Cipriano, 1987). Serum Fe measurements can also be used to monitor recovery from inflammation in horses that have undergone castration (Jacobsen et al., 2005). Jacobsen et al. (2009) reported that serum Fe levels decreased within $24 \mathrm{~h}$ postoperatively in horses with osteochondritic lesions, laryngeal neuropathy, and (or) ovarian tumors. It has also been reported that serum $\mathrm{Fe}$ decreased in animals with experimentally induced bovine respiratory disease and bovine mastitis but they did not correlate the alterations in $\mathrm{Fe}$ with other indicators of inflammation (Lohuis et al., 1990; Erskine and Bartlett, 1993; Middleton et al., 2004; Aich et al., 2009). In the current study, serum Fe concentration decreased in both the mastitis and RPT groups compared with the controls, which indicates that serum $\mathrm{Fe}$ analysis would be a useful tool for the diagnosis of inflammation in cattle suffering from these diseases. Some factors unrelated to inflammation may also alter plasma Fe concentrations. Hypoproteinemia, severe Fe deficiency, and renal disease can reduce plasma Fe concentrations, which could lead to false-positive results. Hemolytic anemia, Fe overload, and liver disease can increase plasma $\mathrm{Fe}$ concentrations, which could result in a false-negative result (Jones and Allison, 2007). To avoid confounding factors, the current study included only those animals in which we did not observe any 
clinical or laboratory findings of the diseases that may have altered plasma Fe levels. The cows, kept and fed under same conditions as the diseased animals, were designated as the control group but the serum profile of the cows in the control group showed low levels of GLU and ALB. The explanation of these results is not easy, but some methodological and physiological (e.g., prolonged negative energy and nitrogen balance) reason could have contributed to that condition.

\section{CONCLUSIONS}

The results of this study indicate that serum Fe analysis in conjunction with other inflammatory markers may be a useful diagnostic tool for acute inflammation in cattle. Because serum Fe measurement is individually available and easily applicable, it may be used for clinical cases as well as the determination of herd health, preferably in combination with other markers of inflammation.

\section{ACKNOWLEDGMENTS}

This research was supported by The Scientific and Technological Research Council of Turkey (TUBITAK, Ankara, Turkey), project number 1080863 .

\section{REFERENCES}

Aich, P., L. A. Babiuk, A. Potter, and P. Griebel. 2009. Biomarkers for prediction of bovine respiratory disease outcome. OMICS 13:199-209.

Andriopoulos, B., Jr., E. Corradini, Y. Xia, S. A. Faasse, S. Chen, L. Grgurevic, M. D. Knutson, A. Pietrangelo, S. Vukicevic, H. Y. Lin, and J. L. Babitt. 2009. BMP6 is a key endogenous regulator of hepcidin expression and iron metabolism. Nat. Genet. 41:482-487.

Baron, S., and C. Lee. 2006. Host response to injury, acute inflammatory response. Pages 70-75 in General Pathology. 4th ed. S. Baron and C. Lee, ed. Lange Pathology McGraw-Hill, New York, NY.

Borges, A. S., T. J. Divers, T. Stokol, and O. H. Mohammed. 2007. Serum iron and plasma fibrinogen concentrations as indicators of systemic inflammatory diseases in horses. J. Vet. Intern. Med. 21:489-494.

Ceciliani, F., J. J. Ceron, P. D. Eckersall, and H. Sauerwein. 2012. Acute phase proteins in ruminants. J. Proteomics 75:4207-4231.

Cherayil, B. J. 2011. The role of iron in the immune response to bacterial infection. Immunol. Res. 50:1-9.

Cheville, N. F. 1999. Acute inflammation. Pages 105-119 in Introduction to Veterinary Pathology. 2nd ed. N. F. Cheville, ed. Blackwell Publishing, Oxford, UK.

Coles, E. H. 1986. Veterinary Clinical Pathology. 4th ed. Pages 90-91. W. B. Saunders Co., Philadelphia, PA and London, UK.

De Domenico, I., D. M. Ward, C. Langelier, M. B. Vaughn, E. Nemeth, W. I. Sundquist, T. Ganz, G. Musci, and J. Kaplan. 2007. The molecular mechanism of hepcidin-mediated ferroportin downregulation. Mol. Biol. Cell 18:2569-2578.

Erskine, R. J., and P. C. Bartlett. 1993. Serum concentrations of copper, iron, and zinc during Escherichia coli-induced mastitis. J. Dairy Sci. 76:408-413.
Forsberg, C. M., and J. J. Bullen. 1972. The effect of passage and iron on the virulence of Pseudomonas aeruginosa. J. Clin. Pathol. 25:65-68.

Gånheim, C., S. Alenius, and K. Persson Waller. 2007. Acute-phase proteins as indicators of calf herd health. Vet. J. 173:645-651.

Gruys, E., M. J. M. Toussaint, T. A. Niewold, and S. J. Koopmans. 2005. Acute phase reaction and acute phase proteins. J. Zhejiang Univ. Sci. B 6:1045-1056.

Harvey, J. W. 2001. Leukocytes. Pages 45-80 in Atlas of Veterinary Hematology. J. W. Harvey, ed. Saunders Co., Philadelphia, PA.

Hayes, M. A. 1994. Functions of cytokines and acute-phase proteins in inflammation. Pages 1-7 in Proc. 6th Congress of the International Society for Animal Clinical Biochemistry (ISACB), Guelph, Canada. J. H. Lumsden, ed. University of Guelph, Guelph, ON, Canada.

Hershko, C., J. D. Cook, and C. A. Finch. 1974. Storage iron kinetics. VI. The effect of inflammation on iron exchange in the rat. Br. J. Haematol. 28:67-75.

Hirvonen, J. 2000. Hirvonen's Thesis on Acute Phase Response in Dairy Cattle. Master of Veterinary Medicine. University of Helsinki Faculty of Veterinary Medicine Publications, Helsinki, Finland.

Horadagoda, N. U., K. M. G. Knox, H. A. Gibbs, and S. W. J. Reid 1999. Acute-phase proteins in cattle: Discrimination between acute and chronic inflammation. Vet. Rec. 144:437-441.

Jacobsen, S., J. C. Jensen, S. Frei, A. L. Jensen, and M. B. Thoefner. 2005. Use of serum amyloid a and other acute phase reactants to monitor the inflammatory response after castration in horses: A field study. Equine Vet. J. 37:552-556.

Jacobsen, S., J. V. Nielsen, M. Kjelgaard-Hansen, T. Toelboell, J. Fjeldborg, M. Halling-Thomsen, T. Martinussen, and M. B. Thoefner. 2009. Acute phase response to surgery of varying intensity in horses: A preliminary study. Vet. Surg. 38:762-769.

Jones, M. L., and R. W. Allison. 2007. Evaluation of the ruminant complete blood cell count. Vet. Clin. North Am. Food Anim. Pract. 23:377-402.

Kluger, M. J., and B. A. Rothenburg. 1979. Fever and reduced iron: Their interaction as a host defense response to bacterial infection. Science 203:374-376.

Kumar, R. K., and D. Wakefield. 2010. Inflammation: Chronic. Pages 1-7 in Encyclopedia of Life Sciences. John Wiley \& Sons Ltd., Chichester, UK.

Lohuis, J. A., Y. H. Schukken, J. H. Verheijden, A. Brand, and A. S. Van Miert. 1990. Effect of severity of systemic signs during the acute phase of experimentally induced Escherichia coli mastitis on milk production losses. J. Dairy Sci. 73:333-341.

Lohuis, J. A. C. M., J. H. M. Verheijden, C. Burvenich, and A. S. J. P. A. M. van Miert. 1988a. Pathophysiological effects of endotoxins in ruminants. 1. Changes in body temperature and reticulorumen motility and the effects of repeated administration. Vet. Q. 10:109-116.

Lohuis, J. A. C. M., J. H. M. Verheijden, C. Burvenich, and A. S. J. P. A. M. van Miert. 1988b. Pathophysiological effects of endotoxins in ruminants. 2. Metabolic aspects. Vet. Q. 10:117-125.

Middleton, J. R., C. D. Luby, L. Viera, J. W. Tyler, and S. Casteel. 2004. Influence of Staphylococcus aureus intramammary infection on serum copper, zinc, and iron concentrations. J. Dairy Sci. 87:976-979.

Morris, D. D. 2009. Alterations in the erythron. Pages 400-410 in Large Animal Internal Medicine. 4th ed. B. P. Smith, ed. Mosby, Philadelphia, PA.

Murata, H., N. Shimada, and M. Yoshioka. 2004. Current research on acute phase proteins in veterinary diagnosis: An overview. Vet. J. $168: 28-40$

Nemeth, E., M. S. Tuttle, J. Powelson, M. B. Vaughn, A. Donovan, D. M. Ward, T. Ganz, and J. Kaplan. 2004. Hepcidin regulates cellular iron efflux by binding to ferroportin and inducing its internalization. Science 306:2090-2093.

Neumann, S. 2003. Serum iron level as an indicator for inflammation in dogs and cats. Comp. Clin. Pathol. 12:90-94. 
Petersen, H. H., J. P. Nielsen, and P. M. H. Heegaard. 2004. Application of acute-phase protein measurements in veterinary clinical chemistry. Vet. Res. 35:163-187.

Radostits, O. M. 2000. Clinical examination of cattle and calves. Pages 151-176 in Veterinary Clinical Examination and Diagnosis. 1st ed. O. M. Radostits, I. G. J. Mayhew, and D. M. Houston, ed. Saunders, London, UK.

Ratledge, C., and L. G. Dover. 2000. Iron metabolism in pathogenic bacteria. Annu. Rev. Microbiol. 54:881-941.

Samols, D., A. Agrawal, and I. Kushner. 2002. Acute-phase proteins. In Cytokine References Online. Academic Press, London, UK. Accessed Dec. 23, 2009. http://tr.scribd.com/doc/59426816/SamolsD-Agrawal-a-Kushner-I-Acute-Phase-Proteins-s.

Schalm, O. W., and D. O. Noorlander. 1957. Experiments and observations leading to development of the California mastitis test. J. Am. Vet. Med. Assoc. 130:199-204.

Smith, J. E., and J. E. Cipriano. 1987. Inflammation-induced changes in serum iron analyses and ceruloplasmin of Shetland ponies. Vet. Pathol. 24:354-356.
Sunder-Plasmann, G., S. I. Patruta, and W. H. Hörl. 1999. Pathobiology of the role of iron in infection. Am. J. Kidney Dis. 34(Suppl. 2):S25-S29.

Thomas, J. S. 2000. Overview of plasma proteins. Pages 891-898 in Schalm's Veterinary Hematology. 5th ed. B. F. Feldman, J. G. Zinkl, and N. C. Jain, ed. Lippincott Williams \& Wilkins, Philadelphia, PA.

Thrall, M. A. 2006. Interpretation of leukocyte responses in disease. Pages 135-148 in Veterinary Hematology And Clinical Chemistry. M. A. Thrall, ed. Blackwell Publishing, Oxford, UK.

Ward, C. G., J. J. Bullen, and H. J. Rogers. 1996. Iron and infection: New developments and their implication. J. Trauma 41:356-364.

Ward, P. A. 2010. Part I. The inflammatory response-An overview. Acute and chronic inflammation. Pages 1-16 in Fundamentals of Inflammation. C. N. Serhan, P. A. Ward, and D. W. Gilroy, ed. Cambridge University Press, New York, NY. 